\title{
Investigating Predictors of Plant Establishment During Roadside Restoration
}

\author{
Nathan L. Haan, ${ }^{1}$ MaryCarol R. Hunter ${ }^{1}$ and Mark D. Hunter ${ }^{2,3}$
}

\begin{abstract}
Ecological restoration on roadsides confers several ecological benefits, but also poses significant challenges. Native plants used in restoration efforts must survive compacted soil, harsh microclimates, prolific invasive species, and pollution from road salts and vehicle emissions. Criteria for both site and species selection need to be developed to assist practitioners in restoring roadside environments. We transplanted seedlings of 9 grassland plant species into plots within 8 highway interchanges surrounding Ann Arbor, Michigan, United States. To see if they might predict plant performance in roadside restoration, we assessed 2 indices: the coefficient of conservatism (CC) as an index of affinity to undisturbed habitat; and the number of U.S. counties in which each species occurs as an index of distribution. We measured seedling survival, height, and biomass during the first growing season, and survival 1 year after transplant.
\end{abstract}

We also measured soil characteristics, air temperature, and humidity at each interchange. We found that soil characteristics largely determined plant survival. Plants were more likely to survive in sandier soils than in soils rich in silt or clay that had high bulk density, high $\mathrm{pH}$, and high conductivity. Although plant survival varied among species and interchanges, neither $\mathrm{CC}$ nor county-level distribution was a useful predictor of survival. Our results illustrate the importance of matching plant species with local soil characteristics when choosing restoration sites, and offer guidance to transportation officials considering roadside restoration with native plants, and practitioners working to restore any heavily disturbed site.

Key words: coefficient of conservatism, highway restoration, microclimate, plant distribution, soil compaction, urban ecosystems.

\section{Introduction}

Ecological restoration of roadsides has the potential to ameliorate some adverse environmental effects of roads while restoring habitat and landscape connectivity. Restoring roadside vegetation can provide erosion control (Andres \& Jorba 2000; Tormo et al. 2007) while improving habitat for wild insects (Ries et al. 2001; Hunter \& Hunter 2008). In urban areas, the exit infields of highway interchanges represent dominant landscape features for city dwellers, and offer opportunities for biodiversity conservation (Helden \& Leather 2004), aesthetic improvements and promoting sense of place (Hunter \& Hunter 2008), and public engagement in ecological restoration (Leather \& Helden 2005).

Roadsides are challenging environments to restore. Roadside microclimates can include high temperatures and low humidity, making seedling establishment difficult (Forman et al. 2003). Many roadside soils are made up of "fill" — an

\footnotetext{
${ }^{1}$ School of Natural Resource and Environment, University of Michigan, Ann Arbor, MI 48109, U.S.A.

2 Department of Ecology and Evolutionary Biology, University of Michigan,

Ann Arbor, MI 48109, U.S.A.

${ }^{3}$ Address correspondence to M. D. Hunter, email mdhunter@umich.edu

imported soil and gravel substrate that lacks the stratified layers typical of undisturbed soils and often lacks topsoil (Forman et al. 2003). Soils are often compacted by construction and maintenance equipment (Berli et al. 2003), which can be detrimental to seedling establishment (Bochet et al. 2010). De-icing salts directly suppress native vegetation (Thompson \& Rutter 1986), and facilitate invasion of wet areas by salttolerant species (Jodoin et al. 2007). Roadside soils are often nitrogen-enriched by $\mathrm{NO}_{x}$ from vehicle emissions, facilitating the spread of nitrogen-capitalizing invasive plants (Davis et al. 2000). In addition to providing habitat for invasive species, highway edges facilitate their rapid dispersal (Von der Lippe and Kowarik 2007).

Several authors have studied restoration of roadsides, mostly focusing on revegetation with native plants (e.g. Andres \& Jorba 2000; Tormo et al. 2008; Bochet et al. 2010). However, despite recent progress, the U.S. Federal Highway Administration's manual for using native vegetation on roadsides states that "the practice remains more of an art than a science" (Harper-Lore \& Wilson 1999). To our knowledge, no studies have examined broad criteria for site selection for roadside restoration. Likewise, choosing appropriate plant species for roadside restoration remains challenging. Although specific plant traits are sometimes associated with successful restoration (Karim \& Mallik 2008; Tormo et al. 2008), simple indices 
of plant suitability, easily available to practitioners, remain elusive.

We established two goals for our study. First, we sought to associate the survival and growth of plant seedlings in experimental plots on highway interchanges with soil and climatic conditions in each plot. In this way, we hoped to determine characteristics of sites that facilitate restoration efforts. Second, we assessed the predictive value of the Coefficient of Conservatism (CC), which estimates the affinity of plants for preEuropean settlement habitat, and the number of U.S. counties in which plants grow, to seedling establishment. We hypothesized that plants with a strong affinity for habitats typical of pre-European settlement (high $\mathrm{CC}$ ), and plants with narrow geographic ranges, would perform poorly in the disturbed habitats of highway interchanges.

\section{Methods}

\section{Study Species}

We used nine broad-leaved herbaceous species for our study, each of which typically grows in open grassland environments and is native to southeastern Michigan. Prairie restoration efforts typically use a combination of grass and herb species, applied directly as seed (Wilson \& Gerry 1995). Our focus on flowering herbs in urban interchanges reflects current research interest in the aesthetic value of restoration in urban landscapes (Gobster et al. 2007), and the potential use of roadside flowering herbs as sources of nectar and pollen for pollinating insects (Saarinen et al. 2005; Hopwood 2008; Hunter \& Hunter 2008).

We selected native plant species along continua from (1) wide to narrow distribution and (2) high to low affinity for pre-European settlement habitat. Our goal was to test the utility of two different indices that can be easily obtained by restoration practitioners. First, we considered each species' CC. Michigan's native plants have each been assigned a coefficient (0-10), with larger numbers representing higher allegiance to undisturbed habitats resembling those that predate European settlement, and smaller numbers assigned to plants that grow in more disturbed sites (Hermann et al. 2001, after Swink \& Wilhelm 1994). Second, we counted the number of U.S. counties in which each species is known to occur (USDA
2010). Despite some undoubted bias in sampling and record keeping, plant species that occupy more U.S. counties may be more widely distributed and could be suited to a broader range of soil conditions and climates. Here, we are able to test experimentally the value of this index for plant selection in roadside restoration. Table 1 lists the species that we selected and their respective CC scores and U.S. county distributions. We planted species with coefficients ranging from 1 to 8. We did not select any species with CCs greater than eight, as they are typically extremely allegiant to specific habitat types, are usually rare, and often their seeds are not commercially available. Such species would be unlikely candidates for roadside restoration efforts. We note that the native plant species we selected are typical of prairie or human disturbed sites in Michigan, and grow on a range of soil types from clay to sand (Table 1) and from dry to wet conditions (Voss 1985, 1996).

Seeds for this study were purchased and germinated in spring 2009. Seeds of all, but one species had been collected from populations in southeast Lower Michigan. Seeds of Asclepias syriaca were collected from a population in northern Lower Michigan because they were not available for purchase locally. Eight of the nine species were germinated in 512-cell flats at WildType nursery (Mason, MI, U.S.A.). As seedlings emerged, they were transferred to $3.8 \times 3.8 \times 5.7 \mathrm{~cm}$ cells, with one plant per cell. Seeds of A. syriaca were germinated in Petri dishes and transferred directly to the larger cells. We used Sun Gro Metro-mix 300 Series growing medium (Sun Gro Canada Ltd., Toronto ON, Canada) in these cells. All seedlings were kept in a greenhouse for 10 days, then outdoors under partial shade for 1 week, and then full sun for 1 week until transplant into the field. Transplanting was completed between 10 June and 16 June 2009. Seedlings were watered sparingly twice after transplant to ensure some seedling survival during two periods of low summer rainfall. We recognize that drought tolerance is a desirable characteristic to assess for roadside restoration. However, seedlings would likely have experienced near total mortality without minimal water applications during the two driest periods of summer, and some level of maintenance is not uncommon during the earliest stages of restoration efforts (Wilson \& Gerry 1995).

Table 1. Plant species used to investigate roadside restoration in southeast Michigan, with coefficients of conservatism, the number of U.S. counties in which each species occurs and known affinities for soil texture.

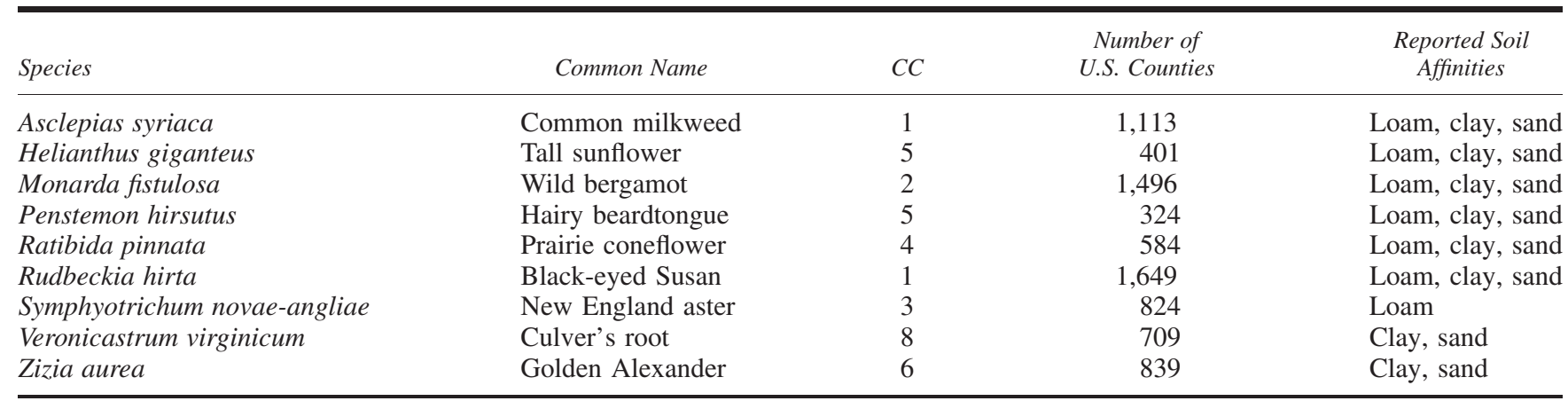

A high $\mathrm{CC}$ reflects species with strong preference for undisturbed sites. 


\section{Experimental Design}

This study was conducted on highway interchanges surrounding Ann Arbor, Michigan, United States $\left(42^{\circ} 17^{\prime} \mathrm{N}, 83^{\circ} 45^{\prime} \mathrm{W}\right.$; Fig. 1). Soils in the area are mostly till and glacial outwash. Annual precipitation in Ann Arbor averages $90 \mathrm{~cm}$ and temperatures vary from average monthly highs in July of $28^{\circ} \mathrm{C}$ to average monthly lows in January of $-9^{\circ} \mathrm{C}$ (US climate data available from http://www.usclimatedata.com). Experimental plantings were located on eight "exit infields" (hereafter referred to as "sites"). An exit infield is the vegetated area enclosed by an exit/entrance ramp and the highway itself. We used infields because they are usually free of development, provide excellent potential areas for restoration, are dominant features of urban landscapes, and are safer and easier to access than the linear highway verge. Sites were located across an area spanning approximately $18 \times 25 \mathrm{~km}$ (Fig. 1).

Each site contained two plots and each plot contained replicate plantings of each species. The plots were arranged to capture topographic variability within each site; where possible, we positioned one plot closer to the paved road surface and the other nearer the center of the infield. However, plot locations were limited by the shapes of the sites and by permitting restrictions (they were required to be at least $11 \mathrm{~m}$ away from road edges). As a result, we could not make systematic comparisons of "center" and "edge," but rather viewed plots as capturing within-site variation. Paired plots were approximately $25 \mathrm{~m}$ away from each other. All plots were in areas that received full sun exposure.

Each plot contained nine subplots, one for each plant species. Each subplot contained 16 individuals of one of the nine plant species. Subplot locations within each plot were randomized. Each plot measured $6.5 \times 6.5 \mathrm{~m}$, and each subplot was $1.5 \times 1.5 \mathrm{~m}$, with $1 \mathrm{~m}$ between each of the subplots. Before planting, a brush cutter was used to trim all vegetation to about $30 \mathrm{~cm}$ height throughout the study area, including a 1-m buffer in all directions from the plots. Additionally, at each subplot, we removed all aboveground plant material with a brush cutter. We installed the 16 seedlings of each species in each subplot in a $4 \times 4$ grid, with $30 \mathrm{~cm}$ between each seedling. Seedlings were planted directly into mown turf and surrounding vegetation was allowed to regrow

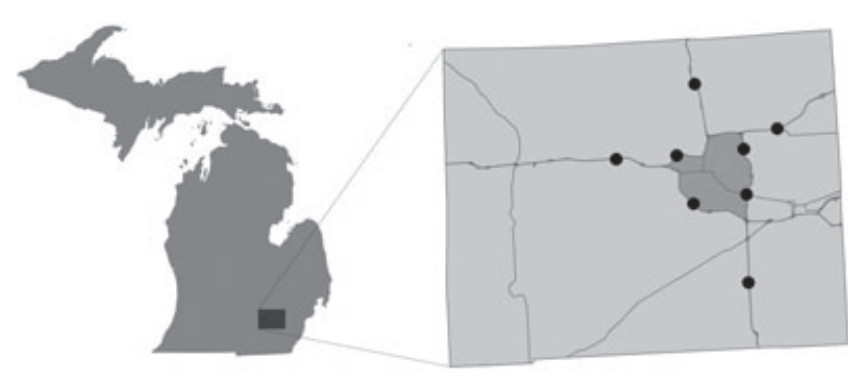

Figure 1. Location of eight sites used to study roadside restoration in Washtenaw County, Michigan, United States. Sites were located on highway interchanges in and around the city of Ann Arbor. during the study to assess the relative performance of our chosen plants under competition with the local community.

\section{Measuring Plant Performance}

We recorded survivorship for all seedlings in September 2009, approximately 3 months after planting. We measured height of all surviving plants (from soil to tip of highest leaf) and assessed damage from herbivores for all individuals (yes/no). In late September 2009, we harvested a random sample of five living seedlings from each subplot at one of two plots at each site, and measured above and belowground biomass. Finally, we visited sites in June 2010, 1 year after planting, to record overwintering survival rates for all plants. One site was destroyed by road construction and could not be sampled in 2010.

\section{Sampling Environmental Conditions}

We installed HOBO Pro Temp v2 dataloggers (Onset Corporation, Pocasset, MA, U.S.A.) at each site to track air temperature and relative humidity. Loggers were mounted to wooden posts $20 \mathrm{~cm}$ above the soil surface, and shielded from direct sunlight by ventilated white plastic covers. We recorded temperature and relative humidity at each site every 30 minutes for the duration of the study.

We took soil samples from each plot during October 2009 to estimate soil bulk density, percent sand silt and clay, soil $\mathrm{pH}$ and electrical conductivity (hereafter, soil characteristics). These soil characteristics are relatively easy for managers and practitioners to measure, yet provide reliable predictors of many soil processes (Coleman et al. 2004). Bulk density was measured as the average of four samples taken using a steel soil core. Soil was collected to a depth of $20 \mathrm{~cm}$; density was determined by dividing the mass of the collected soil by the volume of the interior of the core. We quantified the percent sand, silt, and clay of soil from each plot using the hydrometer method (Bouyoucos 1936). We measured the $\mathrm{pH}$ and electrical conductivity of soil from each plot using SevenMulti $\mathrm{pH}$ and conductivity meters (Mettler Toledo, Columbus, OH, U.S.A.). Soil samples were mixed in a 1:1 ratio with deionized water, and the supernatant was measured after the solution had settled for 1 day.

\section{Statistical Analysis}

The soil characteristics that we measured were not independent of one another, so we used principal components analysis (PC-ORD 5.10) to generate independent multivariate axes describing variation in soil characteristics among plots. A single axis model was the most parsimonious (eigenvalue $=$ 4.53, explaining $74.2 \%$ of the variance, no other axis had an eigenvalue exceeding 1). We used this single axis of soil characteristics in all subsequent analysis relating soil quality to plant performance. The axis distinguished higher sand content on one end, and higher silt, clay, $\mathrm{pH}$, electrical conductivity, and bulk density on the other. 
We used mixed model analysis of variance (Proc Mixed, SAS 9.2) to examine whether overwintering survivorship varied by site, plant species, or their interaction. Plant species and site were fixed effects, whereas plot nested within site was a random effect (Quinn \& Keough 2002). All survival data were arcsine square root transformed prior to analysis to meet assumptions of normality and Tukey's test was used to explore differences among treatment mean values. We assessed correlations between CC scores or plant distributions and overwintering survival of plants using nonparametric Spearman rank correlation (Proc Corr, SAS 9.2). Similarly, we assessed correlations between plant overwintering survival and soil Principal Components Analysis (PCA) scores using Spearman rank correlation. Because indices of plant performance met assumptions of normality, we used generalized linear models (Proc GLM, SAS 9.2) to assess whether plant height, belowground biomass, aboveground biomass, or total biomass in September 2009 predicted overwintering survival to 2010. Likewise, we used GLM to assess correlations between overwintering survival and climatic variables at each site; to avoid issues of type I error arising from multiple correlation analyses, we restricted ourselves to those correlations we considered most ecology appropriate. Specifically, we assessed correlations between overwintering survival and (1) average daily minimum relative humidity, (2) average daily relative humidity, (3) average daily maximum temperature, and (4) average daily temperature. In doing so, we assumed that the stresses of aridity and high temperature were the most likely climatic factors to influence overwintering survival. Analysis of 2009 data includes data from all sites and plots. Analysis of 2010 data lacks data from the one site ( $=2$ plots) lost to road construction (above).

\section{Results}

\section{Plant Performance}

Plant survival after 1 year varied among plant species $\left(F_{[8,62]}=2.93, \quad p=0.0078\right.$; Table 2A) and among interchanges $\left(F_{[6,62]}=11.33, p<0.0001\right.$, Table $\left.2 \mathrm{~B}\right)$, but there was no discernable species by interchange interaction $\left(F_{[48,62]}=\right.$ $1.01, p=0.48$ ) suggesting that the rank of species survival did not vary among interchanges. Overall, Zizia aurea exhibited the greatest rate of overwintering survival, whereas Asclepias syriaca exhibited the lowest; other species were intermediate in their rates of survival (Table 2A).

Despite these differences in overwintering survival among species, neither $\mathrm{CC}$ nor county-level distribution was related statistically to the overwintering survival of plants $(p=$ 0.70 for distribution in U.S. counties, $p=0.48$ for CC). Measures of plant performance in September 2009 (height, biomass, and herbivore damage) were generally poor predictors of survival to summer 2010 (Table 3). Two of nine species (Monarda fistulosa, Penstemon hirsutus) exhibited positive correlations between height and overwintering survival, one species (A. syriaca) exhibited a positive correlation between belowground biomass and overwintering survival, and one species $(P$. hirsutus $)$ exhibited a negative correlation
Table 2. Mean overwintering survival rates of seedlings used in roadside restoration in southeast Michigan (Survival data are presented by species $[\mathrm{A}]$ and site $[\mathrm{B}])$.

\begin{tabular}{|c|c|c|c|c|c|}
\hline \multirow[t]{10}{*}{$A$} & $\begin{array}{l}\text { Tukey } \\
\text { Grouping }\end{array}$ & Species & $\begin{array}{l}\text { Mean \% } \\
\text { Surviving }\end{array}$ & $S E$ & $N$ \\
\hline & A & Zizia aurea & 73.86 & 8.89 & 14 \\
\hline & $\mathrm{AB}$ & $\begin{array}{l}\text { Helianthus } \\
\quad \text { giganteus }\end{array}$ & 67.69 & 9.72 & 14 \\
\hline & $\mathrm{AB}$ & Rudbeckia hirta & 65.58 & 10.26 & 14 \\
\hline & $\mathrm{AB}$ & Monarda fistulosa & 64.12 & 11.63 & 14 \\
\hline & $\mathrm{AB}$ & Ratibida pinnata & 62.09 & 11.79 & 14 \\
\hline & $\mathrm{AB}$ & $\begin{array}{l}\text { Veronicastrum } \\
\text { virginicum }\end{array}$ & 55.56 & 8.89 & 14 \\
\hline & $\mathrm{AB}$ & Penstemon hirsutus & 50.64 & 11.13 & 14 \\
\hline & $\mathrm{AB}$ & $\begin{array}{c}\text { Symphyotrichum } \\
\text { novae-angliae }\end{array}$ & 50.16 & 9.79 & 14 \\
\hline & B & Asclepias syriaca & 30.07 & 9.87 & 14 \\
\hline \multirow[t]{8}{*}{$B$} & $\begin{array}{l}\text { Tukey } \\
\text { Grouping }\end{array}$ & \multicolumn{3}{|c|}{$\begin{array}{l}\text { Mean \% } \\
\text { Surviving }\end{array}$} & $N$ \\
\hline & A & 2 & & 7.19 & 18 \\
\hline & $\mathrm{AB}$ & 7 & & 5.17 & 18 \\
\hline & $\mathrm{AB}$ & 3 & & 4.98 & 18 \\
\hline & $\mathrm{AB}$ & 8 & & 7.86 & 18 \\
\hline & $\mathrm{BC}$ & 5 & & 9.49 & 18 \\
\hline & $\mathrm{BC}$ & 1 & & 11.17 & 18 \\
\hline & $\mathrm{C}$ & 6 & & 7.41 & 18 \\
\hline
\end{tabular}

Tukey groupings not sharing a letter differ significantly from one another. Although survival data were transformed prior to analysis, untransformed data are shown for ease of interpretation.

Table 3. Regression analyses between measures of plant performance and overwintering survival of plant species used in roadside restoration in southeastern Michigan.

\begin{tabular}{|c|c|c|c|c|c|}
\hline Species & Height & $A G B$ & $B G B$ & $\begin{array}{c}\text { Total } \\
\text { Biomass }\end{array}$ & $\begin{array}{c}\% \\
\text { Damaged }\end{array}$ \\
\hline \multirow[t]{2}{*}{ Asclepias syriaca } & 0.25 & 0.70 & 0.88 & 0.79 & -0.39 \\
\hline & 0.09 & 0.12 & 0.02 & 0.06 & 0.21 \\
\hline \multirow{2}{*}{$\begin{array}{l}\text { Helianthus } \\
\text { giganteus }\end{array}$} & 0.52 & 0.09 & 0.18 & 0.13 & -0.34 \\
\hline & 0.06 & 0.84 & 0.70 & 0.78 & 0.24 \\
\hline \multirow{2}{*}{$\begin{array}{l}\text { Monarda } \\
\text { fistulosa }\end{array}$} & 0.69 & 0.25 & 0.17 & 0.22 & -0.28 \\
\hline & 0.0097 & 0.58 & 0.71 & 0.63 & 0.35 \\
\hline \multirow{2}{*}{$\begin{array}{c}\text { Penstemon } \\
\text { hirsutus }\end{array}$} & 0.59 & 0.64 & 0.63 & 0.64 & -0.66 \\
\hline & 0.045 & 0.12 & 0.13 & 0.12 & 0.02 \\
\hline \multirow[t]{2}{*}{ Ratibida pinnata } & 0.40 & 0.40 & 0.53 & 0.44 & -0.30 \\
\hline & 0.15 & 0.37 & 0.21 & 0.31 & 0.29 \\
\hline \multirow[t]{2}{*}{ Rudbeckia hirta } & 0.21 & 0.39 & 0.20 & 0.34 & -0.44 \\
\hline & 0.51 & 0.39 & 0.66 & 0.44 & 0.15 \\
\hline \multirow{2}{*}{$\begin{array}{r}\text { Symphyotrichum } \\
\text { novae-angliae }\end{array}$} & 0.27 & 0.31 & 0.24 & 0.30 & 0.53 \\
\hline & 0.38 & 0.49 & 0.6 & 0.51 & 0.06 \\
\hline \multirow{2}{*}{$\begin{array}{l}\text { Veronicastrum } \\
\text { virginicum }\end{array}$} & 0.20 & 0.09 & -0.23 & -0.12 & -0.39 \\
\hline & 0.53 & 0.84 & 0.62 & 0.8 & 0.21 \\
\hline \multirow[t]{2}{*}{ Zizia aurea } & 0.43 & 0.34 & 0.35 & 0.35 & -0.17 \\
\hline & 0.16 & 0.45 & 0.44 & 0 & 0.61 \\
\hline
\end{tabular}

Plant performance measures were made in September 2009 (height, aboveground biomass [AGB], belowground biomass [BGB], total biomass, percent damaged), whereas overwintering survival was measured in June 2010. Data are regression coefficients, with $p$ values below in italics. Values in bold are significant at the $5 \%$ level or better. However, none remain statistically significant after Bonferroni adjustment for multiple comparisons. 
Table 4. Soil texture, bulk density $\left(D_{\mathrm{b}}\right)$, electrical conductivity (EC), and $\mathrm{pH}$ at eight highway interchanges used in roadside restoration in southeastern Michigan.

\begin{tabular}{lccccccc}
\hline Site & Plot & $\%$ Sand & $\%$ Silt & $\%$ Clay & $D_{b}\left(\mathrm{~g} / \mathrm{cm}^{3}\right)$ & $E C(\mu \mathrm{S} / \mathrm{cm})$ & $p H$ \\
\hline 1 & 1 & 33 & 32 & 35 & 1.51 & 469 & 8.52 \\
& 2 & 34 & 33 & 33 & 1.41 & 1,485 & 8.43 \\
2 & 1 & 72 & 19 & 9 & 1.12 & 345 & 7.58 \\
& 2 & 67 & 21 & 12 & 1.21 & 479 & 7.49 \\
3 & 1 & 55 & 26 & 19 & 1.51 & 344 & 7.56 \\
& 2 & 49 & 35 & 16 & 1.37 & 471 & 7.85 \\
4 & 1 & 72 & 19 & 9 & 1.08 & 296 & 7.5 \\
& 2 & 68 & 24 & 8 & 1.16 & 305 & 7.6 \\
5 & 1 & 44 & 29 & 27 & 1.16 & 547 & 8.18 \\
& 2 & 46 & 28 & 26 & 1.27 & 680 & 7.69 \\
6 & 1 & 36 & 33 & 31 & 1.24 & 847 & 8.13 \\
& 2 & 33 & 40 & 27 & 1.42 & 1,264 & 8.03 \\
7 & 1 & 59 & 25 & 16 & 1.11 & 464 & 7.42 \\
& 2 & 65 & 22 & 13 & 1.20 & 521 & 7.51 \\
8 & 1 & 60 & 21 & 19 & 1.41 & 435 & 7.76 \\
& 2 & 59 & 25 & 16 & 1.43 & 484 & 7.92 \\
\hline
\end{tabular}

between percent of individuals damaged by herbivores and overwintering survival (Table 3). However, none of these regressions was statistically significant after applying Bonferroni's adjustment for multiple comparisons.

\section{Abiotic Conditions}

Soil characteristics varied significantly among sites (Table 4), with soil texture classifications ranging from sandy loam (coarsest texture) to clay loam (finest texture). We found a strong positive correlation between soil PCA score and overwintering survival of plants. This positive relationship holds true whether plots are averaged within sites $(N=7$ surviving sites, Spearman's Rho $=0.929, p=0.0025)$ or plots are treated independently within sites $(N=14$ surviving plots, Spearman's Rho $=0.661, p=0.01)$. We illustrate the latter in Figure 2 to provide the greatest visual range in soil characteristics, whereas the former has stronger statistical justification. In either case, overwintering survival increases strongly with an increasing proportion of sand in the soil, and with concomitant decreases in silt, clay, bulk density, $\mathrm{pH}$, and conductivity (Fig. 2). There were no significant relationships between temperature or humidity and overwintering survival ( $p$ values range from 0.09 to 0.60 ).

\section{Discussion}

Urban soils can differ dramatically from those in less disturbed areas (Pavao-Zuckerman 2008) and our study demonstrates that soil physical and chemical properties are useful predictors of native seedling survival on roadway interchanges. Plants were more likely to survive in sandier soils than in soils rich in silt or clay, with high bulk density, and with high $\mathrm{pH}$ and conductivity. It follows that site selection for roadside prairie restoration in Lower Michigan should prioritize sandy soils. This is not because our chosen plant species grow poorly on clay soils per se (Voss 1985, 1996). Indeed, prairie plants

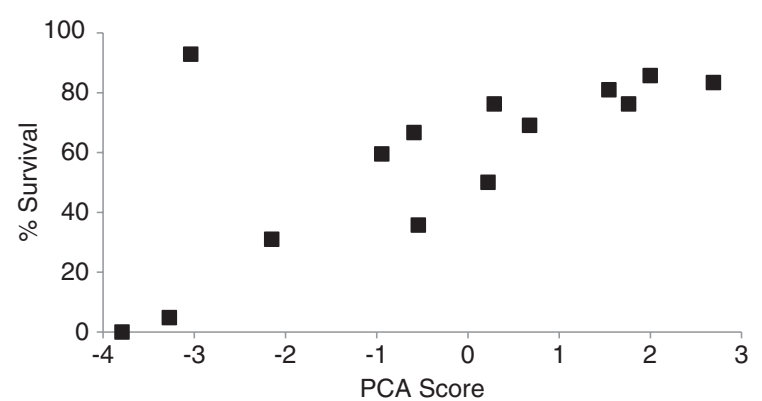

Figure 2. Effects of soil characteristics on overwinter survival of seedlings used in roadside restoration in southeast Michigan. Data represent the averages of nine species at each of 14 plots ( 2 of 16 plots were lost to road construction). Larger values on the PCA axis represent plots with sandier soils; lower scores represent plots with more silt, clay, greater bulk density, and higher $\mathrm{pH}$ and conductivity.

occur on a wide variety of soil types within Michigan (Kost et al. 2007). Rather, clay soils appear to magnify the negative aspects of roadside disturbance in several key ways.

First, compaction and concomitant declines in oxygen availability to roots impede seedling root growth (Bochet et al. 2010), and clay soils had higher bulk densities. A study of a woodland restoration on a capped landfill found that roots could not penetrate the compacted-clay cap (Handel et al. 1997). Similarly, high bulk density on road shoulders contributed to extremely low species diversity in Newfoundland (Karim \& Mallik 2008). In our study, soils with smaller particle size were more compacted, despite the fact that clay soils typically have lower bulk densities than coarse-textured soils in natural conditions (Brady \& Weil 2002). Bulk density at some plots was as high as $1.5 \mathrm{~g} / \mathrm{cm}^{3}$, which approaches the threshold beyond which roots cannot penetrate clay soils. At the other extreme, soils at three plots with less than $10 \%$ clay content had bulk densities around $1.1 \mathrm{~g} / \mathrm{cm}^{3}$, which is typical of soils in uncultivated grassland systems (Brady \& Weil 2002).

Additionally, clay soils are poorly drained and may retain more salts and pollutants than sandy soils (Strek \& Weber 1982; Brady \& Weil 2002), making them more vulnerable to acute contamination. Levels of conductivity at most of our study sites were slightly higher than those reported at sites with similar soil textures in Michigan (100-400 $\mu \mathrm{S} / \mathrm{cm}$; Chatterjee \& Lal 2009). Nearly all plants died at two of our plots with especially high electrical conductivity $(1,200-1,400 \mu \mathrm{S} / \mathrm{cm})$, offering evidence that ions in soil solution, probably from road salt, contributed to plant mortality at our study sites. Soils in our plots were also more alkaline than those reported for non-roadside soils of similar type in Michigan $(\mathrm{pH}=6-7$; Chatterjee \& Lal 2009), perhaps because roadside "fill" lacks the stratification and weathering of older soils, and may reflect the calcareous character of unweathered soil parent materials typical of this region.

It is also possible that the nine plant species we selected were simply better adapted to dry sandy soils than to clay soils. However, published habitat preferences for our nine species suggest that they grow under a wide variety of soil conditions (Voss 1985, Voss 1996). For example, Symphyotrichum 
novae-angliae is typically found in moist to wet ground, shrubby swamps, and wet prairies (Voss 1996) and Zizia aurea inhabits low swampy areas and boggy ground (Voss 1996). All nine plant species used in our experiments are reported growing from sand, clay and loam soils across a range of habitat types. We conclude that our species pool was not overrepresented by sand-loving species and that our results reflect the general unsuitability of compacted-clay soils of high conductivity and $\mathrm{pH}$ to support native seedling establishment.

Measures of plant height and mass in 2009 were poor predictors of subsequent overwintering survival suggesting that restoration practitioners in Michigan should not use seedling size in the first season as a metric of likely establishment success. Relationships between plant performance between the 2 years may have been compromised by herbivores; in several cases, aboveground portions of the plants were removed by herbivores, meaning that otherwise-healthy plants had low estimates of biomass and growth. Herbivory can certainly limit plant establishment during ecological restoration (Opperman \& Merenlender 2000). In our study, however, herbivory had minimal impact on subsequent survival; only one species, $P$. hirsutus, exhibited a significant reduction in overwinter survival based on herbivore damage.

Plant species differed in their rates of overwintering survival. We note that the species with the lowest survivorship, Asclepias syriaca, was the only species grown from seed that was not local-A. syriaca seed came from the northern part of the lower peninsula of Michigan and genotypes may not have been climatically matched to conditions in the southeast of the state. Other studies have emphasized the importance of using local genotypes for restoration efforts (Bischoff et al. 2010) and our data appear to support that idea, especially given that A. syriaca is certainly capable of growing in roadsides in the southeast of Michigan; it is a common member of roadside communities around Ann Arbor, but established poorly from nonlocal seed. However, experimental work would be required to compare the relative performance of local and nonlocal genotypes before firm conclusions could be drawn.

Differences in overwintering survival among plant species were unrelated to either $\mathrm{CC}$ or plant distribution. Moreover, effects of soil characteristics on plant survival were much stronger than were effects of plant identity. Therefore, although species selected for roadside restoration projects will likely perform differently from one another, the indices we examined in this study were not useful predictors of performance from the seedling stage though the first year of establishment. Because we planted seedlings and did not plant seeds directly into highway interchanges, we cannot rule out the possibility that the $\mathrm{CC}$ or number of counties in which plants occur might be related to seed germination and initial establishment. It is also possible that these indices could predict restored plant community composition over longer time periods, but this hypothesis would need to be pursued by way of a longer-term study. Plant traits can sometimes be predictive of performance during restoration. For example, seed mass can be a useful predictor of species establishment on drought-prone roadsides where plants are established by seeding (Tormo et al. 2008). We did not measure seed mass in our study, but our use of seedlings instead of seeds likely minimized potential effects of seed mass on establishment; seed mass generally has its greatest impact on plant performance during the earliest stages of growth (Moles \& Westoby 2006). However, predicting species performance based on single traits is generally difficult, and considering combinations of traits for each species is more likely to yield predictive results (Roberts et al. 2010). There are also alternative methods of estimating the range of conditions under which plants might establish, including climate envelope modeling (Iverson et al. 2004) and experimental studies in which species are grown in replicated treatments that vary in abiotic and biotic conditions (Howard 2010). These alternatives hold significant promise as estimates of plant suitability for restoration efforts, although any benefits that they might provide would have to be weighed against significantly higher costs of collecting the data.

Our study differs from typical prairie restorations in two ways. First, our focus was on flowering herbs, in part because of the importance of aesthetic value to public perception of restoration efforts in urban areas in which we work (Parsons \& Daniels 2002). Second, to monitor individual plants and guarantee equal replication of plants in plots, we used young seedlings in interchanges instead of applying seeds. This had the advantage of allowing us to follow in detail the fate of 2,304 individual plants over the course of the study. However, seedling establishment is only one part of any restoration effort and the relative effects of soil characteristics and plant traits on long-term restoration success need to be examined in more detail. Future work should investigate the effects of soil characteristics, species mix and plant traits on reproduction, germination and emergence rates, vulnerability to invasion by exotic species, roles of fungal symbionts, pollution, and salt tolerance.

\section{Implications for Practice}

- Our findings demonstrate the importance of considering soil characteristics when selecting from among severely disturbed sites for ecological restoration.

- Restoration plans in southern Lower Michigan that include transplants of the nine species examined here should prioritize sandy soils for restoration efforts.

- Simple indices such as a plant's CC or the breadth of its distribution are not useful predictors of whether seedlings will establish in the harsh roadside environment.

- Areas that receive run-off from highways can be inhospitable for native species. They may require alternative de-icing agents, altered application methods, or a palette of species that are highly tolerant to salt and/or pollutants.

\section{Acknowledgments}

Thanks to D. Zak, I. Ibáñez, and B. Batt for advice and logistical support. Matthaei Botanical Gardens and Nichols 
Arboretum provided additional logistical support while B. Schneider at WildType Nursery provided seedlings for the experiment. R. Vannette, J. Wang, G. Honik, R. Bokhari, S. Kabat, H. Gan, L. Tao, L. Durfee, S. Mates, M. Hutchins, and J. Lalor helped with lab and fieldwork. Three anonymous reviewers provided useful guidance during revision. This project was funded in part by the SNRE Thesis Research Grant and the Matthaei Botanical Gardens and Nichols Arboretum Research Endowment Fund Award.

\section{LITERATURE CITED}

Andres, P., and M. Jorba. 2000. Mitigation strategies in some motorway embankments (Catalonia, Spain). Restoration Ecology 8:268-275.

Berli, M., J. M. Kirby, S. M. Springman, and R. Schulin. 2003. Modeling compaction of agricultural subsoils by tracked heavy construction machinery under various moisture conditions in Switzerland. Soil \& Tillage Research 73:57-66.

Bischoff, A., T. Steinger, and H. Muller-Scharer. 2010. The importance of plant provenance and genotypic diversity of seed material used for ecological restoration. Restoration Ecology 18:338-348.

Bochet, E., P. Garcia-Fayos, and J. Tormo. 2010. How can we control erosion of roadslopes in semiarid Mediterranean areas? Soil improvement and native plant establishment. Land Degradation \& Development 21:110-121.

Bouyoucos, G. J. 1936. Directions for making mechanical analysis of soils by the hydrometer method. Soil Science 42:225-229.

Brady, N. C., and R. R. Weil. 2002. The nature and properties of soils. $13^{\text {th }}$ edition. Pearson Education Inc., Upper Saddle River, New Jersey.

Chatterjee, A., and R. Lal. 2009. On farm assessment of tillage impact on soil carbon and associated soil quality parameters. Soil \& Tillage Research 104:270-277.

Coleman, D. C., D. A. Crossley, and P. F. Hendrix. 2004. Fundamentals of soil ecology. Elsevier Academic Press, Amsterdam, The Netherlands.

Davis, M. A., J. P. Grime, and K. Thompson. 2000. Fluctuating resources in plant communities: a general theory of invasibility. Journal of Ecology 88:528-534

Forman, R. T. T., D. Sperling, J. A. Bissonette, A. P. Clevenger, C. D. Cutshall, V. H. Dale, et al. 2003. Road ecology: science and solutions. Island Press, Washington, D.C.

Gobster, P. H., J. L. Nassauer, T. C. Daniel, and G. Frey. 2007. The shared landscape: what does aesthetics have to do with ecology? Landscape Ecology 22:959-972.

Handel, S. N., G. R. Robinson, W. F. J. Parsons, and J. H. Mattei. 1997. Restoration of woody plants to capped landfills: root dynamics in an engineered soil. Restoration Ecology 5:178-186.

Harper-Lore, B., and M. Wilson, editors. 1999. Roadside use of native plants. Federal Highway Administration, Washington, D.C.

Helden, A. J, and S. R. Leather. 2004. Biodiversity on urban roundaboutsHemiptera, management and the species-area relationship. Basic and Applied Ecology 5:367-377.

Herman, K. D., L. A. Masters, M. R. Penskar, A. A. Reznicik, G. S. Wilhelm, W. W. Brodovich, and K. P. Gardiner. 2001. Floristic quality assessment with wetland categories and examples of computer applications for the State of Michigan: revised. $2^{\text {nd }}$ edition. Michigan Department of Natural Resources, Wildlife Division, Natural Heritage Program, Lansing, Michigan.

Hopwood, J. L. 2008. The contribution of roadside grassland restorations to native bee conservation. Biological Conservation 141:2632-2640.

Howard, R. J. 2010. Intraspecific variation in growth of marsh macrophytes in response to salinity and soil type: implications for wetland restoration. Estuaries and Coasts 33:127-138.

Hunter, M. R., and M. D. Hunter. 2008. Designing for conservation of insects in the built environment. Insect Conservation and Diversity 1:189-196.
Iverson, L. R., M. W. Schwartz, and A. M. Prasad. 2004. Potential colonization of newly available tree-species habitat under climate change: an analysis for five eastern US species. Landscape Ecology 19:787-799.

Jodoin, Y., C. Lavoie, P. Villeneuve, M. Theriault, J. Beaulieu, and F. Belzile. 2007. Highways as corridors and habitats for the invasive common reed Phragmites australis in Quebec, Canada. Journal of Applied Ecology 45:459-466.

Karim, M. N., and A. U. Mallik. 2008. Roadside revegetation by native plants I. Roadside microhabitats, floristic zonation and species traits. Ecological Engineering 32:222-237.

Kost, M. A., D. A. Albert, J. G. Cohen, B. S. Slaughter, R. K. Schillo, C. R. Weber, and K. A. Chapman. 2007. Natural communities of Michigan: classification and description. Michigan Natural Features Inventory, Report No. 2007-21, Lansing, Michigan.

Leather, S. R., and A. J. Helden. 2005. Magic roundabouts? Teaching conservation in schools and universities. Journal of Biological Education 39: $102-107$

Moles, A. T., and M. Westoby. 2006. Seed size and plant strategy across the whole life cycle. Oikos 113:91-105.

Opperman, J. J., and A. M. Merenlender. 2000. Deer herbivory as an ecological constraint to restoration of degraded riparian corridors. Restoration Ecology 8:41-47.

Parsons, R., and T. C. Daniels. 2002. Good looking: in defense of scenic landscape aesthetics. Landscape and Urban Planning 60:43-56.

Pavao-Zuckerman, M. 2008. The nature of urban soils and their role in ecological restoration of cities. Restoration Ecology 16:642-649.

Quinn, G. P., and M. J. Keough. 2002. Experimental design and data analysis for biologists. Cambridge University Press, Cambridge, United Kingdom.

Ries, L., D. M. Debinski, and M. L. Wieland. 2001. Conservation value of roadside prairie restoration to butterfly communities. Conservation Biology 15:401-411

Roberts, R. E., D. L. Clark, and M. V. Wilson. 2010. Traits, neighbors, and species performance in prairie restoration. Applied Vegetation Science 13:270-279.

Saarinen, K., A. Valtonen, J. Jantunen, and S. Saarnio. 2005. Butterflies and diurnal moths along road verges: does road type affect diversity and abundance? Biological Conservation 123:403-412.

Strek, H. J, and J. B. Weber. 1982. Behaviour of polychlorinated biphenyls (PCBs) in soils and plants. Environmental Pollution 28:291-312

Swink, F., and G. Wilhelm. 1994. Plants of the Chicago region. Indiana Academy of Science, Indianapolis, Indiana.

Thompson, J. R., and A. J. Rutter. 1986. The salinity of motorway soils IV. Effects of sodium chloride on some native British shrub species, and the possibility of establishing shrubs on the central reserves of motorways. Journal of Applied Ecology 23:299-315.

Tormo, J., E. Bochet, and P. García-Fayos. 2007. Roadfill revegetation in semiarid Mediterranean environments. Part II: topsoiling, species selection, and hydroseeding. Restoration Ecology 15:97-102.

Tormo, J., P. García-Fayos, and E. Bochet. 2008. Relative importance of plant traits and ecological filters in road embankment revegetation under semiarid Mediterranean conditions. Ecological Engineering 33:258-264.

USDA. 2010. Plants Database. Natural Resources Conservation Service, United States Department of Agriculture.

Von der Lippe, M., and I. Kowarik. 2007. Long-distance dispersal of plants by vehicles as a driver of plant invasions. Conservation Biology 21:986-996.

Voss, E. G. 1985. Michigan flora. Part II. Cranbrook Institute of Science Bulletin 59 and University of Michigan Herbarium.

Voss, E. G. 1996. Michigan flora. Part III. Cranbrook Institute of Science Bulletin 61 and University of Michigan Herbarium.

Wilson, S. D., and A. K. Gerry. 1995. Strategies for mixed-grass prairie restoration: Herbicide, tilling, and nitrogen manipulation. Restoration Ecology 3:290-298. 